\title{
Suitability of a Progenitor Cell-Enriching Device for In Vitro Applications
}

\author{
Antonio Celentano ${ }^{1, *}\left(\mathbb{D}\right.$, Tami Yap ${ }^{1}\left(\mathbb{D}\right.$, Giuseppe Pantaleo $^{2}$, Rita Paolini ${ }^{1}$, Michael McCullough ${ }^{1}$ \\ and Nicola Cirillo ${ }^{1}$ \\ 1 Melbourne Dental School, The University of Melbourne, 720 Swanston Street, Carton, VIC 3053, Australia; \\ tspyap@unimelb.edu.au (T.Y.); rita.paolini@unimelb.edu.au (R.P.); m.mccullough@unimelb.edu.au (M.M.); \\ nicola.cirillo@unimelb.edu.au (N.C.) \\ 2 Department of Medicine and Surgery, University of Salerno, Via Salvador Allende, 43, \\ 84081 Baronissi, Salerno, Italy; gpantaleo@unisa.it \\ * Correspondence: antonio.celentano@unimelb.edu.au; Tel.: +61-393-411495
}

Citation: Celentano, A.; Yap, T.;

Pantaleo, G.; Paolini, R.;

McCullough, M.; Cirillo, N

Suitability of a Progenitor Cell-Enriching Device for In Vitro

Applications. Coatings 2021, 11, 146.

https://doi.org/10.3390/

coatings11020146

Academic Editors: Ajay Vikram Singh and Eduardo Guzmán

Received: 30 December 2020

Accepted: 25 January 2021

Published: 28 January 2021

Publisher's Note: MDPI stays neutra with regard to jurisdictional claims in published maps and institutional affiliations.

Copyright: (c) 2021 by the authors. Licensee MDPI, Basel, Switzerland. This article is an open access article distributed under the terms and conditions of the Creative Commons Attribution (CC BY) license (https:// creativecommons.org/licenses/by/ $4.0 /)$.

\begin{abstract}
Rigenera ${ }^{\circledR}$ is a novel class- 1 medical device that produces micro-grafts enriched of progenitors cells without ex vivo manipulation of donor tissues. The manufacturer's protocol has been supported for a wide variety of clinical uses in the field of regenerative medicine. This study aimed to evaluate its potential use for in vitro cell models. Human primary oral fibroblasts were cultured under standard conditions and processed through Rigenera ${ }^{\circledR}$ over a time course of up to $5 \mathrm{~min}$. Cell viability was assessed using a Trypan Blue exclusion test. It is possible to process fibroblasts through Rigenera ${ }^{\circledR}$ although an initial reduction of cell viability was observed. Additionally, debris was evident in the cell suspension of the processed samples. Scanning electron microscopy (SEM) microanalysis of the debris and electron energy-loss spectroscopy confirmed the presence of metal wear possibly due to the processing conditions used in this study. Interestingly, pore sizes within Rigeneracons ${ }^{\circledR}$ grids were found to range between $250-400 \mu \mathrm{m}$. This is the first report assessing the suitability of Rigenera ${ }^{\circledR}$ and Rigeneracons ${ }^{\circledR}$ for in vitro applications. Whilst Rigenera ${ }^{\circledR}$ workflow was found to be amenable to laboratory uses, our results strongly suggest that further research and development is necessary to support the utilization of this technology for enrichment of micro-graft derived cells and cell sorting in vitro.
\end{abstract}

Keywords: Rigenera ${ }^{\circledR}$; stem cells; progenitor cells; multipotent; cell sorting; regeneration

\section{Introduction}

Research in the field of stem cells and their potential application in regenerative medicine have captured attention in the 21st century. The physiological process of tissue regeneration is fundamental for the maintenance of tissues and organs throughout the human body. The importance of stem cells lies in their ability to differentiate into various cell types for the purpose of tissue regeneration.

One promising source of stem cells are those derived from the epidermis [1], including that of the oral mucosa, such as oral keratinocytes and fibroblasts [2,3]. Additionally, the dental pulp has been shown to be a rich source of stem cells [4].

Fibroblasts are abundant within the connective tissue where they maintain the structural integrity of connective tissue by synthesizing and remodelling components of the extracellular matrix and regulate autoimmunity, organ development, wound healing, inflammation and fibrosis [3,5]. Furthermore, fibroblasts exhibit many properties similar to mesenchymal stem cells (MSCs), being both plastic adherent and multipotent cells [3]. The multipotent characteristics of fibroblasts have sparked interest in their use in the field of regenerative medicine.

Although the isolation of stem cells can be achieved, therapeutic application remains a challenge [6]. A major shortcoming that continues to hinder the translation of stem cell research from bench to bedside is the ex vivo manipulation of donor tissues, a necessary 
step to isolate progenitor cells. This is currently achieved using chemical agents. In 2006, Human Brain Wave (HBW) designed Rigenera ${ }^{\circledR}$, a chairside technology introduced as an innovative technique that allows isolation of stem cells from autologous micro-grafts for application in clinical regenerative procedures. Using the Rigenera ${ }^{\circledR}$ protocol, in just one surgical procedure, the patient is both donor and recipient of calibrated micro-grafts. This takes place within a single procedural time and is is capable of enriching micrograft-derived progenitors cells for regeneration within the recipient site [7]. Importantly, this technique is based on a principle of mechanical size-selection, thus reducing the risk of contamination or alteration of the sample. At present, Rigenera ${ }^{\circledR}$ is an innovative and promising application in regenerative medicine, particularly in the fields of dental surgery, dermatology, plastic surgery, maxilla-facial surgery, orthopaedics, aesthetic medicine, and wound healing [7-15].

Rigenera ${ }^{\circledR}$ consists of two main components: The Rigenera ${ }^{\circledR}$ machine, and Rigeneracons ${ }^{\circledR}$ (also known as Medicons ${ }^{\circledR}$ ). The Rigeneracons ${ }^{\circledR}$ are disposable devices activated by the machine that includes a metal steel grid and a blade. The grid is comprised of 100 hexagonal pores with indicated diameter sizes of 25,50 and $75 \mu \mathrm{m}$. The blade is helical in shape and disaggregates the tissue samples placed in the Rigeneracons ${ }^{\circledR}$ creating mechanical friction against the grid at rotational speeds of $80 \mathrm{RPM}$, in the presence of saline solution [7]. Disaggregated single cells are mechanically guided through the pores in the grid, precipitating in a lower chamber from which they are collected with a sterile syringe for clinical use. Separation by cell size selection achieved with the Rigenera ${ }^{\circledR}$ system is the hallmark of the device. Stem cells are known to range from $20-40 \mu \mathrm{m}$ in diameter [16], hence the processed micro-grafts are believed to contain a high population of progenitor cells, thus leading to optimal regenerative potential [12-17]. The processing times of the micro-grafts range from $10 \mathrm{~s}$ to minutes [7].

Research has shown that Rigenera ${ }^{\circledR}$ micro-grafts are rich in MSCs and have a large presence of endothelial cells and pericytes that promote post-traumatic revascularization in tissue regeneration $[7,8,17]$. Additionally, previous studies have demonstrated the in vivo use of Rigenera ${ }^{\circledR}$ technology to improve the healing of bone lesions [18], wound healing [7-9,17-19], and management of ulcers [19]. Nevertheless, because this technology was designed for clinical applications, no information is available about the suitability of this device for potential in vitro application.

Therefore, in the present study we aimed to assess if the Rigenera ${ }^{\circledR}$ workflow could be utilized as an alternative cell sorting technique for laboratory research and further, to characterize the effect of Rigenera ${ }^{\circledR}$ workflow on the viability of primary cultured fibroblasts and on the quality of the processed samples.

\section{Materials and Methods}

\subsection{Isolation of Primary Human Fibroblasts}

Normal oral mucosal tissue was obtained for this study from a healthy patient attending the Royal Dental Hospital of Melbourne (RDHM) for a routine third molar extraction. A $0.5 \mathrm{~mm}^{2}$ oral mucosal sample was excised and placed in a falcon tube containing sterile phosphate-buffered saline (PBS, D8537, Sigma, Castle Hill, NSW, Australia) and $2 \%$ penicillin-streptomycin solution (P4333, Sigma-Aldrich, Castle Hill, NSW, Australia) for $20 \mathrm{~min}$. Effective isolation of primary human fibroblasts from the biopsy sample was achieved with incubation overnight at $4{ }^{\circ} \mathrm{C}$ with $0.5 \% \mathrm{w} / v$ dispase (17105-041, Gibco), mechanical separation of the epithelial layer, and use of selective culture medium. Fibroblast viability and purity were confirmed by Trypan Blue exclusion (Trypan Blue dye, $0.4 \%$ solution, 1450021 , Biorad, UK) and visual assessment with inverted light microscopy (EVOS ${ }^{\mathrm{TM}}$ FLoid ${ }^{\mathrm{TM}}$ Cell Imaging Station, Life Technologies, Cramlington, UK). Ethics approval was obtained for this study (University of Melbourne n. 1340716.1).

\subsection{Cell Culture Techniques}

Primary human fibroblasts were cultured in polystyrene coated 6-well plate (CLS3506, Corning ${ }^{\circledR}$, New York, NY, USA) and grown to $60 \%-80 \%$ confluence before being further 
sub-cultured. Cells were cultured using Dulbecco's Modified Eagle's Medium (DMEM, D5796, Sigma-Aldrich, Castle Hill, NSW, Australia), supplemented with $10 \%$ fetal bovine serum (FBS, SFBS-F, Bovogen, Keilor East, VIC, Australia), and 1\% penicillin streptomycin mixture (P4333, Sigma-Aldrich, Castle Hill, NSW, Australia) in a humidified atmosphere at standard conditions $\left(5 \% \mathrm{CO}_{2}, 37^{\circ} \mathrm{C}\right)$. Cells at confluency were subsequently detached by pre-treatment with $10 \mathrm{mM}$ EDTA for $10 \mathrm{~min}$, followed subsequently with incubation in a $0.25 \%$ trypsin in $1 \mathrm{mM}$ EDTA solution (T4049, Sigma-Aldrich, Castle Hill, NSW, Australia) for $5 \mathrm{~min}$, and re-cultured under standard conditions for 5 passages over a period of 4 weeks before being processed with Rigenera ${ }^{\circledR}$. The viability of the fibroblasts was confirmed at each passage by Trypan Blue exclusion (Trypan Blue Dye, $0.4 \%$ solution, 1450021, Biorad, UK).

\subsection{Effect of Rigenera ${ }^{\circledR}$ Processing on Human Fibroblast Viability In Vitro}

Cultured primary human fibroblasts (at 6th passage) were seeded in 24 well plates (CLS3527, Corning ${ }^{\circledR}$, New York, NY, USA) at a starting density of $0.6 \times 10^{5}$ cells/well and grown under standard conditions over $72 \mathrm{~h}$. Growth medium was replaced every $24 \mathrm{~h}$. Cells were subsequently detached as described above, and divided into 4 groups: the control group (that did not undergo Rigenera ${ }^{\circledR}$ processing) and three groups that were processed using the Rigener ${ }^{\circledR}$ protocol each with separate sterile Rigeneracons ${ }^{\circledR}$ (pore diameter nominal value $=50 \mu \mathrm{m}$ ) for 1,2 and $5 \mathrm{~min}$ respectively irrigated with $1 \mathrm{~mL}$ of culture medium. Following processing, each sample was immediately collected, visualized with an inverted light microscopy (EVOS ${ }^{\mathrm{TM}}$ FLoid ${ }^{\mathrm{TM}}$ Cell Imaging Station, Life technologies) and re-cultured under standard conditions in 24 well plates as above.

Cell count and viability was assessed in each group at $0,24,48$, and $72 \mathrm{~h}$ with a TC10 ${ }^{\mathrm{TM}}$ Automated Cell Counter (Bio-Rad, Hercules, California) and Trypan Blue exclusion test. Data collection included a total of 10 counts for each group and at all time points. The experiment was performed in triplicate.

\subsection{Characterisation of the Degree of Wear of Internal Components of Rigeneracons ${ }^{\circledR}$}

Rigeneracons ${ }^{\circledR}$ devices from the above experiment and a brand new Rigeneracons ${ }^{\circledR}$ were carefully disassembled in a safety cabinet and single internal components were further investigated. The metal blades and the metal steel grids were analysed using Reflected Light Microscopy (Leica S8AP0, equipped with a Leica MC170HD, Leica, Wetzlar, Germany) and a FEI Tecnai F30 scanning electron microscope (SEM) at the Bio21 Advanced Microscopy facility (FEI, Melbourne, Australia).

\subsection{Characterisation of the Debris Particles from Rigenera ${ }^{\circledR}$ Protocol}

To further analyze the debris produced, a separate new Rigeneracons ${ }^{\circledR}$ device was used to process a sample containing UltraPure ${ }^{\mathrm{TM}}$ distilled water (10977023, Invitrogen) alone for one minute using the Rigenera ${ }^{\circledR}$ machine. The resultant solution was collected, placed in a sterile 100-mm Petri plastic dish (Corning ${ }^{\circledR} 430167$, Corning, New York, NY, USA) and visualised under an inverted light microscope to confirm the presence of debris. The sample was then left covered in a dry oven at $40{ }^{\circ} \mathrm{C}$ overnight. Compositional microanalysis via electron energy-loss spectroscopy (EELS), which can provide fast chemical (elemental) analysis of the field-of-view or point-by-point to a spatial resolution of $\sim 4 \mu \mathrm{m}$, was then performed on the sample obtained.

\subsection{Statistical Analysis}

The statistical significance of the data was analyzed with IBM SPSS Statistics (v. 23) software. Normality was determined with Kolmogorov-Smirnov and Shapiro-Wilk normality tests and distribution was normal. Equality of the variance was determined with the F-test prior to conducting paired $t$-test. Comparisons of the 3-time durations were conducted with one-way analysis of variance (ANOVA). Data are reported as mean and standard deviation and differences were considered to be significant when $p$ was $<0.05$. 


\section{Results}

\subsection{Rigenera ${ }^{\circledR}$ Processing Affects Human Primary Fibroblast Viability In Vitro}

Immediately after Rigenera ${ }^{\circledR}$ processing, $(T=0)$, cultured primary human fibroblasts showed a reduction of cell viability compared to unprocessed controls. This effect was significant after a $1 \mathrm{~min}(p<0.001)$ and a $5 \mathrm{~min}(p=0.028)$ processing period (Figure 1a). Cell viability following $1 \mathrm{~min}$ of processing through Rigenera ${ }^{\circledR}$ ranged from $51 \%-100 \%$ while the control group ranged from $83 \%-100 \%$. Cell viability of the Rigenera ${ }^{\circledR}$ group after 5 min processing ranged from $46 \%-91 \%$ while the control group ranged from $60 \%-95 \%$. Cells processed for $1 \mathrm{~min}$ showed also significantly lower viability compared to controls after $48 \mathrm{~h}(p=0.017)$ and $72 \mathrm{~h}(p=0.041)$. Varying the duration of the sample processing between 1,2 and 5 min showed significant differences in re-cultured cells' viability for up to $24 \mathrm{~h}$ (Figure 1b,c). Cell viability immediately after Rigenera ${ }^{\circledR}$ processing was significantly lower in the $5 \mathrm{~min}$ processing duration when compared to the 1 and $2 \mathrm{~min}$ durations $(p=0.021$ and $p=0.019$, respectively). At the $24 \mathrm{~h}$ time point, the viability of the $5 \mathrm{~min}$ processed sample was significantly lower than the 1 and 2 min processing durations $(p=0.037$ and $p=0.005$, respectively). Taken together, these data show that Rigenera ${ }^{\circledR}$ processing determines a timedependent and transitory reduction of cell viability in primary human fibroblasts compared to unprocessed controls.

\section{a}

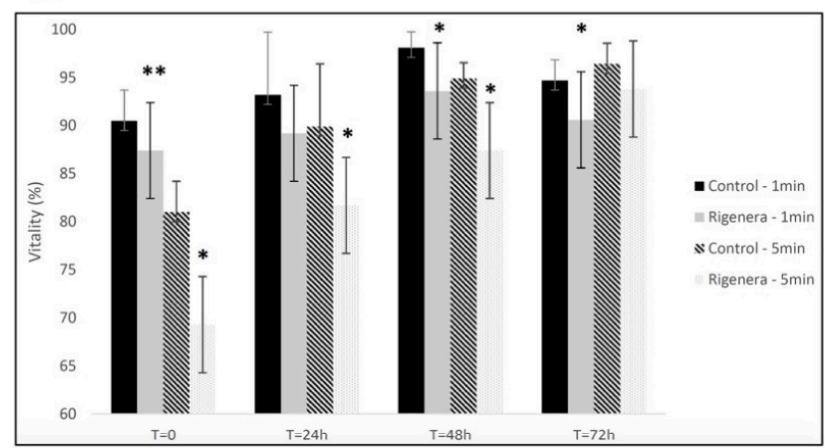

b

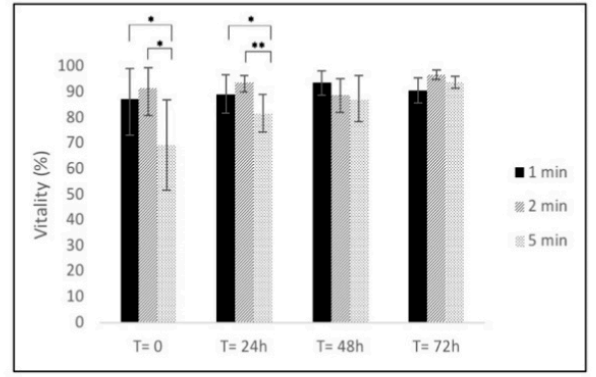

C

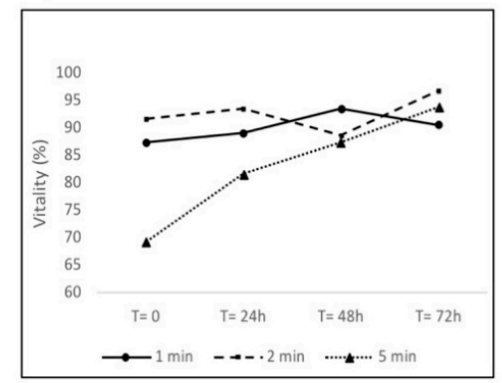

Figure 1. (a) Fibroblast viability for control and samples processed with Rigenera ${ }^{\circledR}$ for 1-min and 5 -min. Significant differences in viability between control and processed cells are indicated as ${ }^{*} p<0.05$ or ${ }^{* *} p<0.01$. (b,c) Viability of fibroblasts at $0 / 24 / 48 / 72 \mathrm{~h}$ time points after being processed with Rigenera ${ }^{\circledR}$ for 1, 2 and 5 min. Statistical significance is given as follows: ${ }^{*} p<0.05 ;{ }^{* *} p<0.01$.

\subsection{Rigenera ${ }^{\circledR}$ Protocol is Associated with the Release of Metal Particles}

Presence of opaque debris was visualized during experiments in all fibroblasts samples processed with Rigenera ${ }^{\circledR}$ (Figure 2). In detail, when inspected under inverted light microscopy, all samples regardless of processing duration presented with heterogenous debris ranging in size from 3-400 $\mu \mathrm{m}$. The amount of debris produced was also found within the cell-free control, which consisted of only UltraPure ${ }^{\mathrm{TM}}$ distilled water (Invitrogen) for one minute (Figures $2 \mathrm{a}$ and $3 \mathrm{a}$ ). The debris collected showed random formation of aggregates in various sizes ranging from $0.1 \mu \mathrm{m}$ to about $400 \mu \mathrm{m}$ in diameter. 
EELS microanalysis of the debris revealed mainly metallic and minute plastic constituents. Elemental point-by-point analysis of the multiple debris particles revealed values ranging between $36.64 \%-52.96 \%$ iron, $7.45 \%-9.31 \%$ chromium, $37.28 \%-37.72 \%$ carbon and about $1 \%$ silica by weight (Figure $3 b-e)$.
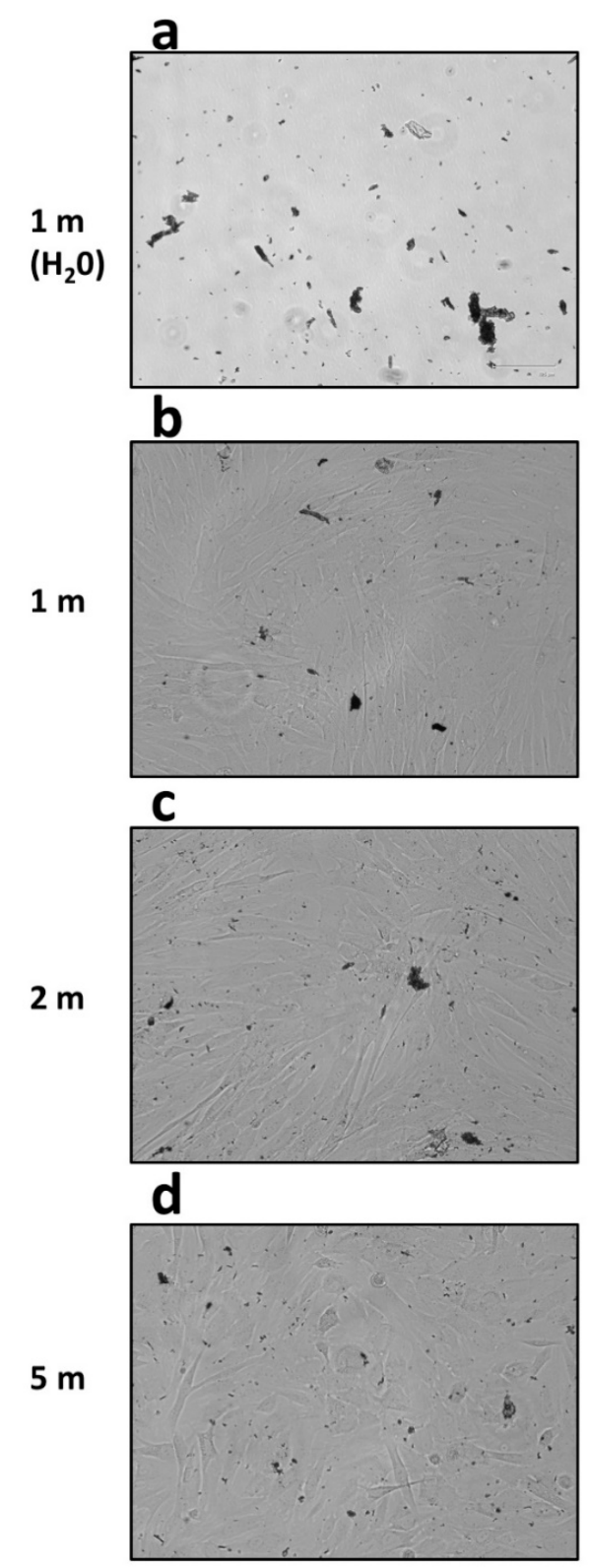

Figure 2. Presence of abundant and heterogenous debris observed at inverted light microscopy in samples processed with Rigenera ${ }^{\circledR}$ (EVOS FLoid Cell Imaging Station, $\times 460$ optical magnification). (a) The cell-free control sample, which consisted of UltraPure ${ }^{\mathrm{TM}}$ distilled water (10977023, Invitrogen) alone processed for $1 \mathrm{~min}$. Fibroblast samples were processed instead for 1, 2, or $5 \mathrm{~min}$ ((b-d) respectively). 

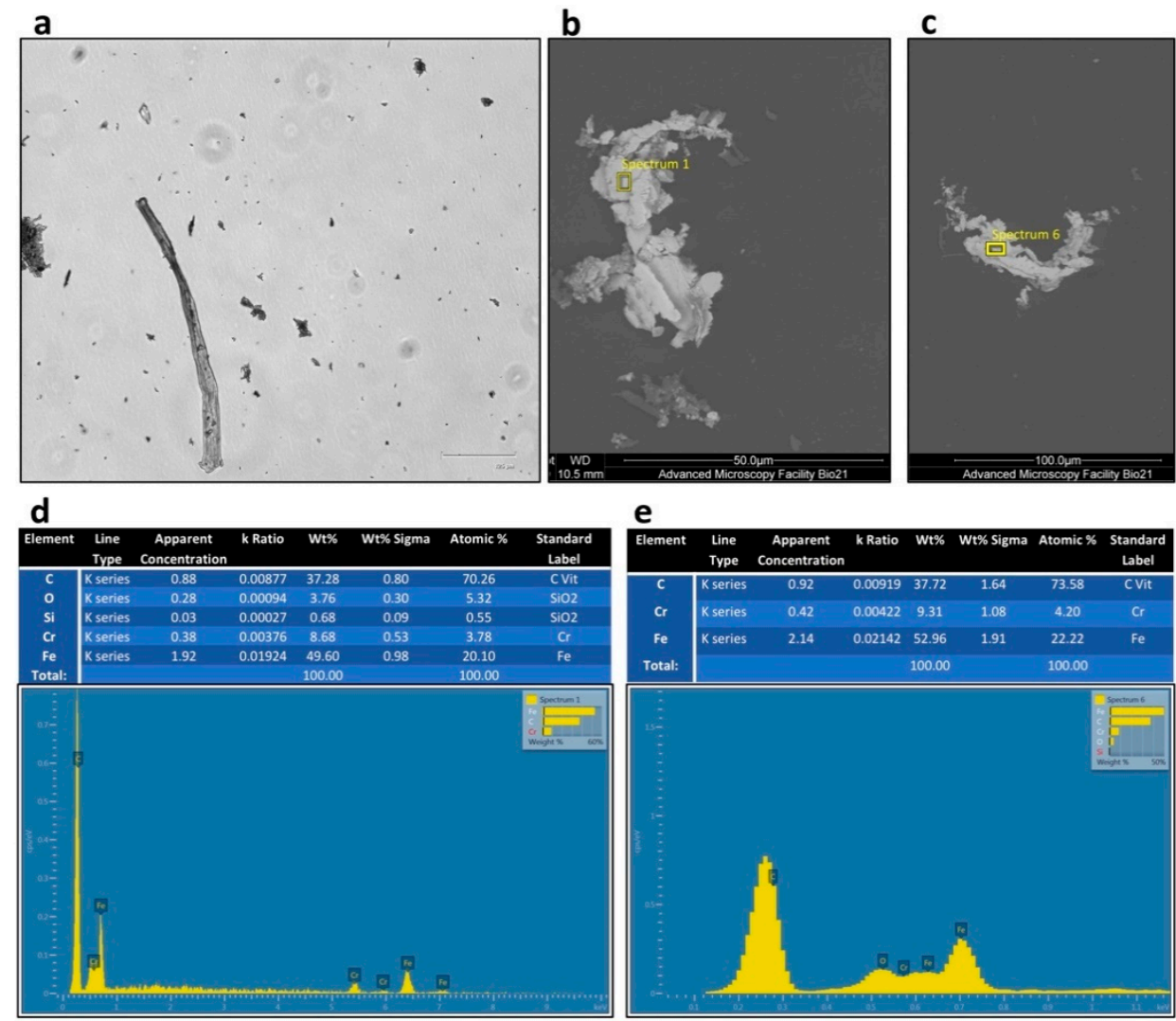

Figure 3. Aspect of the cell-free control sample (UltraPure ${ }^{\mathrm{TM}}$ distilled water alone) processed for 1 min at inverted light microscopy (a) and scanning electron microscopy (SEM) (FEI Tecnai F30) (b,c). Compositional microanalysis via electron energy-loss spectroscopy (EELS) of the debris particles identified in panel b (d) and c (e) respectively. The debris was metallic in nature with primarily iron, carbon, and chromium as its elemental composition by weight. Minute concentrations of Silica was detected.

\subsection{Rigeneracons ${ }^{\circledR}$ Internal Components Show Marked Degree of Wear after Use}

The Rigeneracons ${ }^{\circledR}$ disposable devices were carefully disassembled in a biosafety cabinet after use, and the internal metal components, blades and grids, were analysed under reflected light microscopy and SEM. As expected, macroscopic scratch marks were found on the cutting blades (Figure 4), with the gross size of scratch marks found to be greatest after 5 min of processing. Thus, the longer the Rigeneracons ${ }^{\circledR}$ were processed, the more scratch marks were observed. No visible scratch marks were present on the unused blade when investigated under reflected light microscopy. Subsequently, the metal blades of Rigeneracons ${ }^{\circledR}$ were analysed using SEM. Scans of the blades utilised in the 2 and $5 \mathrm{~min}$ processing durations showed significant surface roughness, consistent with signs of wear, on the front cutting portion of the blades with visible peeling of the edges (Figure 5a) whereas this was not observed in the unused blade. Debris, forming into aggregates of up to $400 \mu \mathrm{m}$, was also found on the blades' surface (Figure 5b-d). 

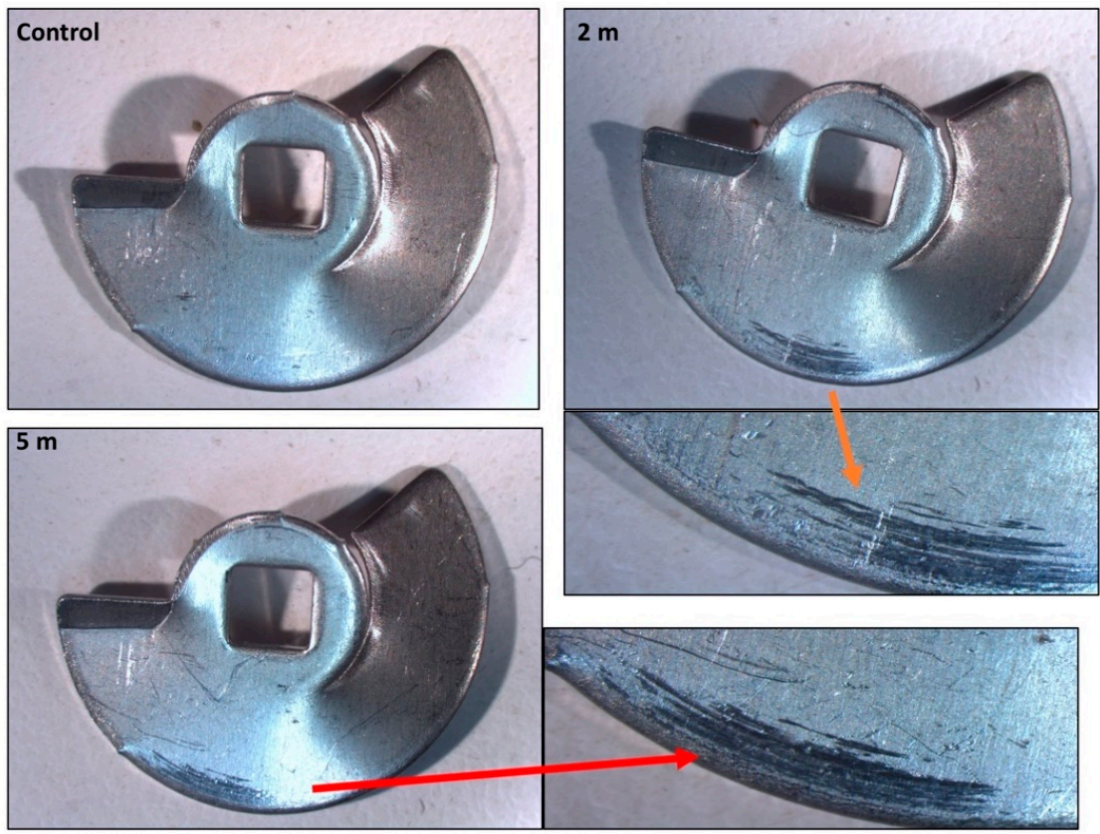

Figure 4. Reflected light microscopy of the Rigeneracons ${ }^{\circledR}$ internal blade when unused (control), after 2 min of processing and after 5-min of processing. The unused blade showed no substantial scratch marks, however, as time of processing was increased, the scratch marks present on the outer rim increased in gross size (greatest after $5 \mathrm{~min}$ ).
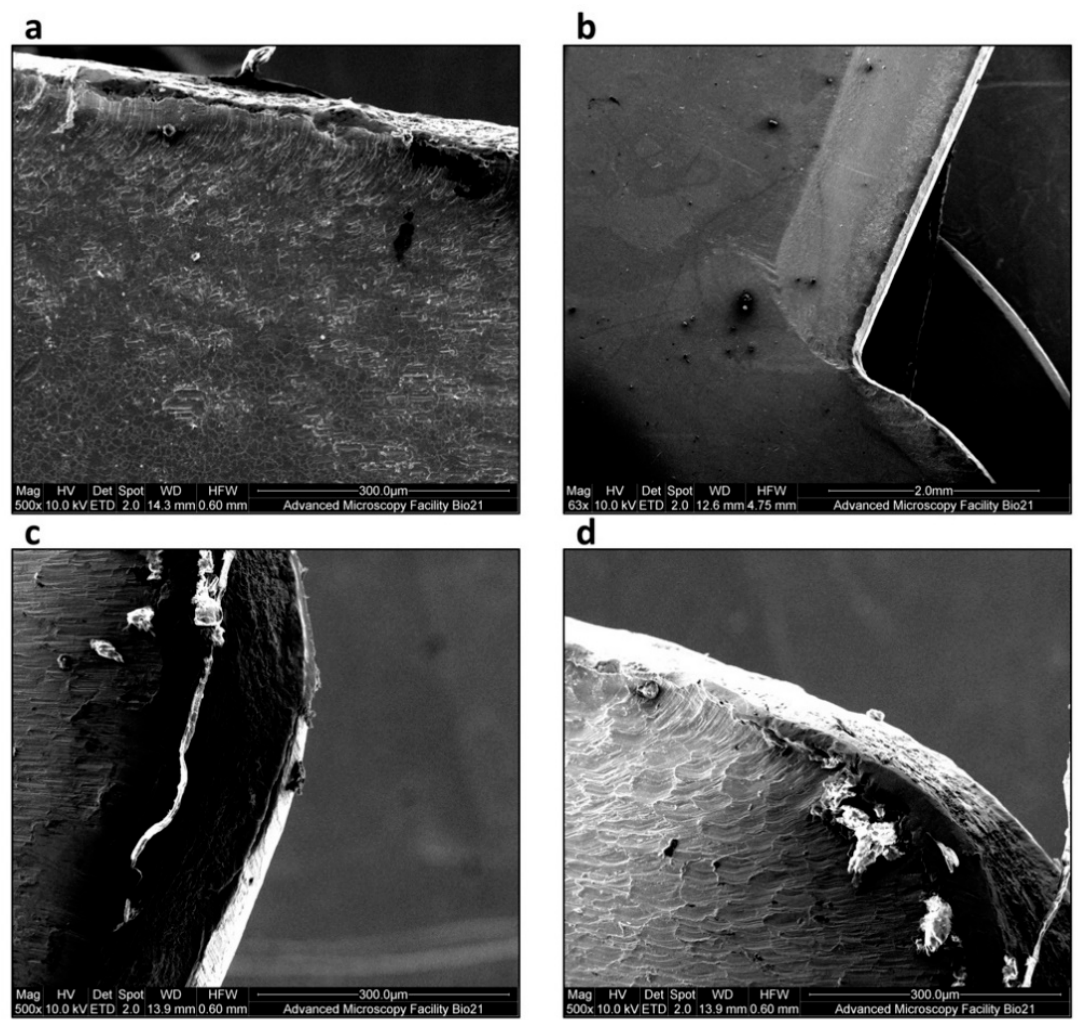

Figure 5. Scanning electron microscope (SEM) observation of blades in Rigeneracons ${ }^{\circledR}$. A blade after 2 min of processing shows evidence of (a) significant wear as damage on the front cutting portion of the blades with visible peeling of the edges. Debris, forming into aggregates of up to $400 \mu \mathrm{m}$, was also found on the blades' surface $(\mathbf{b}-\mathbf{d})$. 


\subsection{Assessment of Pore Size Range}

Given that the metal particle size was larger than the grid's described pore size $(50 \mu \mathrm{m}$ in diameter), the micromorphology of Rigeneracons ${ }^{\circledR}$ grid was inspected. The metallic grids containing the pores designed for individual cell separation based on cell size were analysed using reflected light microscopy. The damaged portions were the cutting edges of the hexagonal pores. The tips of the cutting surfaces appeared to increase in damage proportional to processing time (Figure 6). These findings were confirmed with SEM observation (Figure 7). Abundant debris was additionally detected (Figure 7b). We further observed that the pores size was significantly different from the described diameter of $50 \mu \mathrm{m}$. Pore diameter size was found to range between $250-400 \mu \mathrm{m}$, with an average of about $300 \mu \mathrm{m}$ (Figure $7 \mathrm{c}, \mathrm{d}$ ). The pore size was found to be similar when comparing unused (Figure 7a) and used grids.

Collectively, these data show that the Rigenera ${ }^{\circledR}$ workflow is accompanied by the production of microscopic metal debris. Furthermore, the grid pores are larger than it was expected.
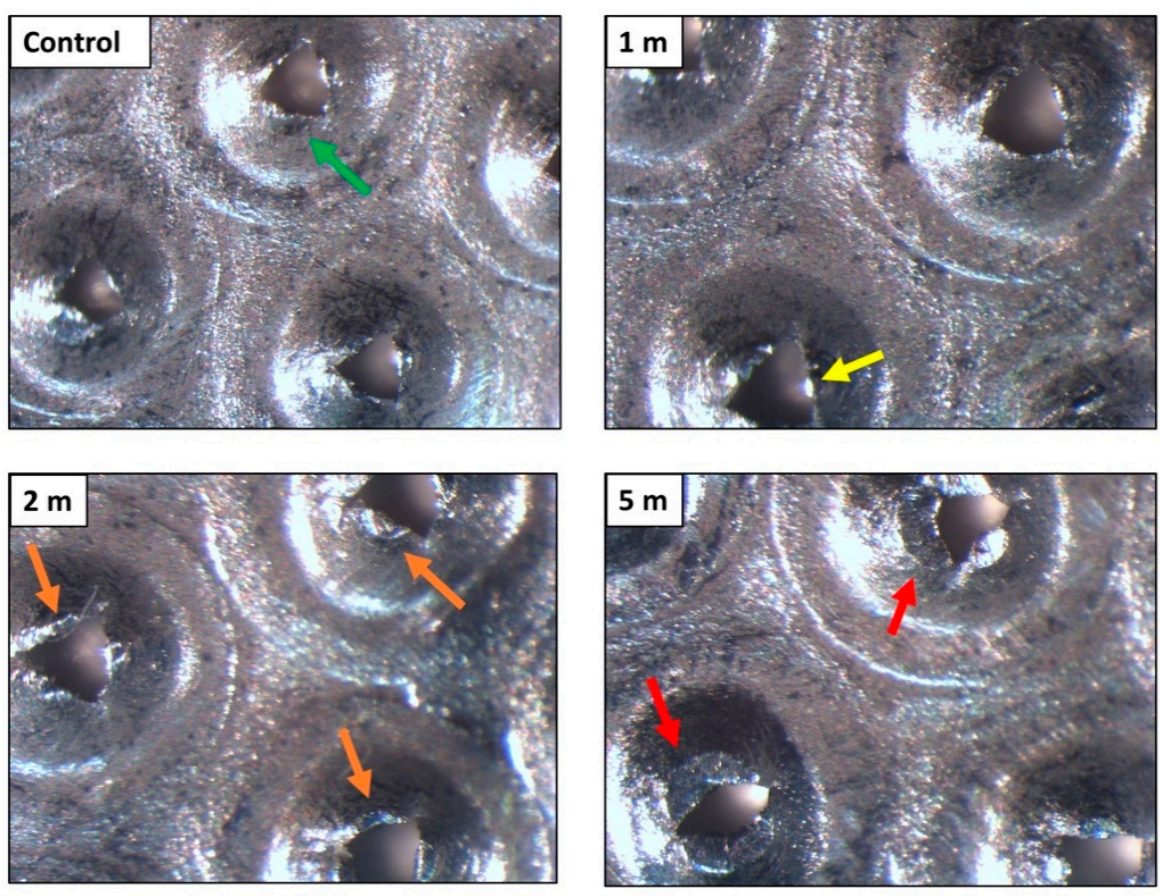

Figure 6. Reflected light microscopy of the Rigeneracons ${ }^{\circledR}$ internal metallic grid when unused (control), after $1 \mathrm{~min}, 2 \mathrm{~min}$ and after $5 \mathrm{~min}$ of processing. The control grid showed no damage of the cutting edges of the hexagonal pores (green arrow). The tips of the cutting surfaces appeared to increase in damage proportional to processing time. The damage ranged from mild wear (yellow arrow), medium wear (orange arrows), up to a complete loss of the cutting edges of the hexagonal pores (red arrows). 
a

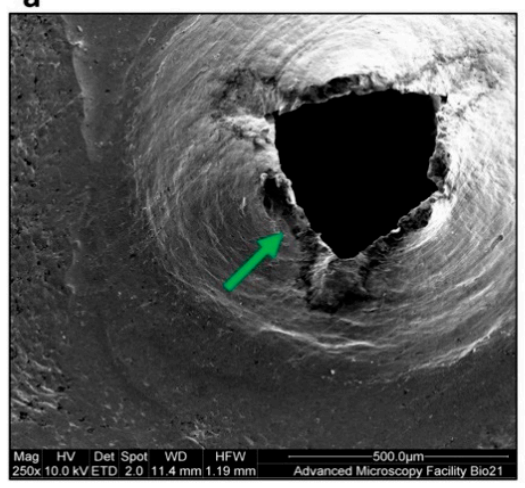

c

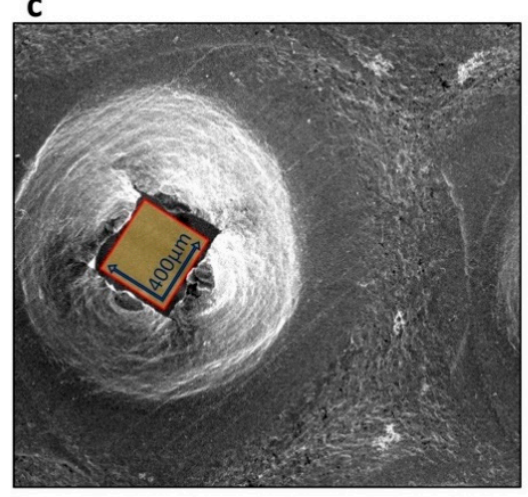

b

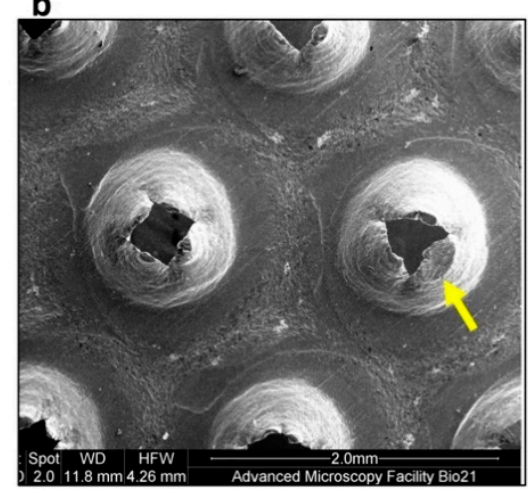

d

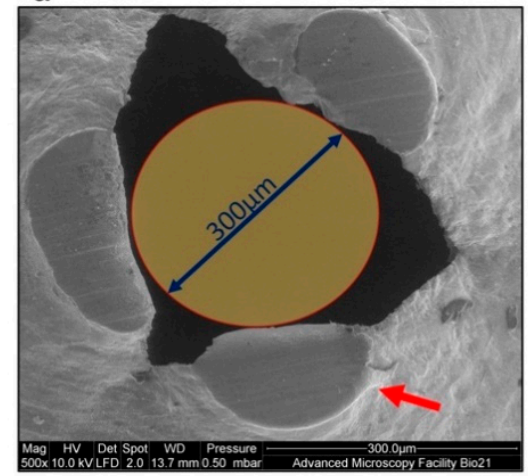

Figure 7. Scanning electron microscope (SEM) observation of the Rigeneracons ${ }^{\circledR}$ steel grid pores. (a) Intact cutting edges of the hexagonal pores (green arrow) in unused disposable device. (b) Spread debris was visible after 2 min of processing together with substantial damage of the cutting edges (yellow arrow). Reference scale measurements show the size of random pores after 5 min of processing. Some of the pores measure just slightly over $400 \mu \mathrm{m}$ in diameter at the widest span (c) and the majority of them allowed the passage of particles with $300 \mu \mathrm{m}$ diameter (d).

\section{Discussion}

This study demonstrates that the Rigenera ${ }^{\circledR}$ protocol can be used in a laboratory setting. However, when applied in vitro, the cell processing determines a significant but transient decrease in viability of cultured fibroblasts. Cells were processed for $5 \mathrm{~min}$ and $30 \%$ decrease in initial viability was observed. The processing of cells with Rigenera ${ }^{\circledR}$ additionally resulted in samples containing debris. The debris was evident in all samples regardless of processing time and appeared to be metal components of the Rigeneracons ${ }^{\circledR}$.

The effect on cell viability when processed using Rigenera ${ }^{\circledR}$ is important for its potential in vitro use, particularly in comparison to current cell-sorting techniques such as fluorescence-activated cell sorting (FACS) and magnet-activated cell sorting (MACS), which are proven to maintain cell vitality $[20,21]$. Therefore, it is important when the Rigenera ${ }^{\circledR}$ protocol is used as an alternative to conventional cell sorting methods in vitro that the vitality is maintained at comparable levels.

In our experimental conditions, the longer the processing time the greater degree of vitality loss, i.e., cell death after 5-min processing was significantly greater than that observed with 1 or 2 min processing. The mechanical effect applied during the separation of cells is speculated to place a significant physiological stress on the fibroblasts, affecting vitality. The decrease in vitality of the $5 \mathrm{~min}$ processing time continued to be significantly lower after $24 \mathrm{~h}$ when compared to the control and the 1 and $2 \mathrm{~min}$ processing durations. This indicates some residual impact on cell vitality after initial processing (Figure $1 \mathrm{~b}$ ). Moreover, cells were monitored for $72 \mathrm{~h}$, witnessing a consistent increase in cell vitality with a peak at $72 \mathrm{~h}$. Cell vitality on fresh tissue samples was not tested in this study, therefore, the possible introduction of cellular debris into the micro-graft may need to be 
further investigated [22,23]. For example, release of intracellular contents from a necrotic cell due to cellular membrane disruption can lead to an increase in inflammation at the site of application [23].

In addition to cellular debris, variably sized metallic residues produced by mechanical wear of the internal components of the Rigeneracons ${ }^{\circledR}$ were found consistently in the processed samples. The presence of metal particles around implants has been reported in the literature for decades, and a recent systematic review highlighted that titanium particles surrounding peri-implant tissues are a common finding [24]. Their size ranged from $100 \mathrm{~nm}$ to $54 \mu \mathrm{m}$ and these were present at a higher number in peri-implantitis sites [24]. In our study, the readings from the BioRad $\mathrm{TC} 10^{\mathrm{TM}}$ counter indicated that the metallic debris had sizes ranging from 4-34 $\mu \mathrm{m}$ in diameter. However, the SEM analysis indicated particles sizes range was much wider than that detected by the Bio-Rad TC10TM counter, which can only detect particles between $4 \mu \mathrm{m}$ and $58 \mu \mathrm{m}$ in diameter [25]. Using SEM, the true size of the debris was more variable, with sizes smaller than $1 \mu \mathrm{m}$ and larger than $400 \mu \mathrm{m}$ in diameter. The debris was found to be composed of iron, carbon, chromium, and occasionally minute readings of silica (Figure 3).

Current literature suggests the presence of metals may have a variety of biological consequences, ranging from direct DNA damage to foreign body reactions in the form of granulomas [26-29]. Chronic exposure to chromium, which was found to be a part of the particle pollution, has been shown to disrupt cellular biological pathways in humans, causing chronic ulceration of the skin and contact dermatitis [29-31]. In vitro studies showed that the presence of chromium led to a direct change in the nuclei shape of fibroblasts, aneuploidy and translocation [32,33], features that have been also implicated in tumour formation [34-36]. In studies of metal-on-metal joint replacements, the presence of metal debris was found to be easily disseminated systemically when the debris was taken up by macrophages, which then traversed to sites distant to the original location of the debris [37]. This is because chromium has been definitively shown to be transported within the bloodstream [38]. Additionally, chromium has also been postulated to cause damage to the liver and spleen due to the lack of elimination via metabolic processes [39-41]. Metals such as chromium can elicit immune responses at $2.2 \mu \mathrm{g} / \mathrm{L}$ [42] and metallic particles ranging from $0.24-7.2 \mu \mathrm{m}$ in size induced the highest pro-inflammatory reaction due to their ability to be taken up by phagocytes, which leads to activation of cellular pathways and release of pro-inflammatory cytokines such as IL-1 $\beta$, IL-6, IL- 8 and TNF $\alpha$ [43].

The largest concentration of metallic pollution found in our samples was in the form of iron, which in studies of metal-on-metal prosthesis have been shown to cause localized tissue damage [27]. Iron particles are generally removed by macrophages and cause no significant damage to the local tissue. However, high iron concentrations can cause cell death, particularly when particle sizes vary between $0.1-3.0 \mu \mathrm{m}$ [26], which was found in our samples. It has to be noted, however, that the magnitude of cytotoxic effects determined by metal particles is significantly higher in in vitro conditions compared to tissues or living organisms, therefore our data do not have a direct clinical implication.

There is also a potential concern over the ability of iron ions to form radical species, specifically hydroxyl radicals, that can cause damage to nearby cells [44-49]. Again, it is difficult to determine whether the study results correlate to similar effects to those in vivo. The long-term effect of trauma and metal ions in this study is unclear. However it should be noted that recovery of cells in culture from $72 \mathrm{~h}$ was evident (Figure 3). Therefore the level of damage and physiological interaction of these metal particles is transient and might not determine host tissue response in vivo. To date, a detrimental effect from grafts use in Rigenera ${ }^{\circledR}$ processed samples has not been reported.

A further critical point of our data is the diameter of the pores in the Rigeneracons ${ }^{\circledR}$. As per manufacturer's project, the principle basis of the machine is its ability to separate samples by selecting for cells smaller than 25,50 and/or $75 \mu \mathrm{m}$ as these have been found to be highly correlated to stem cells and colony-forming units $[1,2,7,11,15]$. When the metal steel grid was examined under SEM, the pore size was found to far exceed that of the upper 
limits. All pores examined had a size of approximately $450 \mu \mathrm{m}$ at its maximum width (Figure 7), and the majority of them allowed the passage of particles with up to $300 \mu \mathrm{m}$ diameter. The improved control in the manufacture of the pore size may have a positive effect on results in vitro and in vivo.

This pilot in vitro study demonstrates that Rigenera ${ }^{\circledR}$ workflow is easy to use and might be amenable to in vitro settings if appropriate modifications were made. Specifically, cell processing with Rigenera ${ }^{\circledR}$ device lowers cell vitality. The possibility of using this system for cell separation needs to be better determined especially with regards to the deviation in detected pore sizes compared to the manufacturers' data. The presence of metallic debris and the potential effects on the host response also need to be further investigated. We suggest that our findings be used as a starting point for improvement of this promising device and may be of value in creating a tool suitable for in vitro application. In summary, the use of Rigenera ${ }^{\circledR}$ for in vitro studies requires further work before a protocol can be determined.

Author Contributions: Conceptualization, A.C. and N.C.; methodology, T.Y;; software, R.P.; validation, A.C., M.M., and G.P.; formal analysis, T.Y.; investigation, A.C.; resources, N.C.; data curation, G.P.; writing—original draft preparation, A.C.; writing—review and editing, N.C.; visualization, A.C. and R.P.; supervision, M.M.; project administration, A.C.; funding acquisition, N.C. All authors have read and agreed to the published version of the manuscript.

Funding: This study was funded in part by Human Brain Wave (HBW) srl, Italy. The authors wish to acknowledge the support of the Melbourne Dental School, The University of Melbourne.

Institutional Review Board Statement: Ethics approval was obtained for this study (University of Melbourne n. 1340716.1).

Informed Consent Statement: Informed consent was obtained from all subjects involved in the study.

Data Availability Statement: Data is contained within the article.

Acknowledgments: A.C. would like to thank Joseph Palamara and Chau Nguyen, Melbourne Dental School, The University of Melbourne, for their guidance with the microscopy analysis. Electron microscopy was carried out at the Bio21 Advanced microscopy facility. The authors gratefully acknowledge the support of the Melbourne Dental School, The University of Melbourne.

Conflicts of Interest: The authors declare no conflict of interest. Specifically, no personal financial support was received from H.B.W. srl.

\section{References}

1. Calenic, B.; Greabu, M.; Caruntu, C.; Tanase, C.; Battino, M. Oral keratinocyte stem/progenitor cells: Specific markers, molecular signaling pathways and potential uses. Periodontol. 2000 2015, 69, 68-82. [CrossRef] [PubMed]

2. Barrandon, Y.; Green, H. Cell size as a determinant of the clone-forming ability of human keratinocytes. Proc. Natl. Acad. Sci. USA 1985, 82, 5390-5394. [CrossRef] [PubMed]

3. Haniffa, M.A.; Collin, M.P.; Buckley, C.D.; Dazzi, F. Mesenchymal stem cells: The fibroblasts' new clothes? Haematologica 2009, 9 , 258-263. [CrossRef] [PubMed]

4. Potdar, P.D.; Jethmalani, Y.D. Human dental pulp stem cells: Applications in future regenerative medicine. World J. Stem Cells 2015, 7, 839-851. [CrossRef] [PubMed]

5. Chang, Y.; Li, H.; Guo, Z. Mesenchymal stem cell-like properties in fibroblasts. Cell. Physiol. Biochem. 2014, 34, 703-714. [CrossRef]

6. Dixit, P.; Katare, R. Challenges in identifying the best source of stem cells for cardiac regeneration therapy. Stem Cell Res. Ther. 2015, 6, 26. [CrossRef]

7. Trovato, L.; Monti, M.; Del Fante, C.; Cervio, M.; Lampinen, M.; Ambrosio, L.; Redi, C.A.; Perotti, C.; Kankuri, E.; Ambrosio, G.; et al. A new medical device rigeneracons allows to obtain viable micro-grafts from mechanical disaggregation of human tissues. J. Cell Physiol. 2015, 230, 2299-2303. [CrossRef]

8. Zanzottera, F.; Lavezzari, E.; Trovato, L.; Icardi, A.; Graziano, A. Adipose derived stem cells and growth factors applied on hair transplantation. follow-up of clinical outcome. J. Cosmet. Dermatol. Sci. Appl. 2014, 4, 268-274. [CrossRef]

9. Rodriguez y Baena, R.; D’Aquino, R.; Graziano, A.; Trovato, L.; Aloise, A.C.; Ceccarelli, G.; Pelegrine, A.A.; Lupi, S.M. Autologous Periosteum-Derived Micrografts and PLGA/HA enhance the bone formation in sinus lift augmentation. Front Cell Dev. Biol. 2017, 5, 87. [CrossRef] 
10. Svolacchia, F.; De Francesco, F.; Trovato, L.; Graziano, A.; Ferraro, G.A. An innovative regenerative treatment of scars with dermal micrografts. J. Cosmet. Dermatol. 2016, 15, 245-253. [CrossRef]

11. Giaccone, M.; Brunetti, M.; Camadona, M.; Trovato, L.; Graziano, M. A new medical device, based on Rigenera Protocol, in the management of complex wounds. J. Stem Cells Res. Rev. Rep. 2014, 1, 1013.

12. Graziano, A.; Carinci, F.; Scolaro, S. Periodontal tissue generation using autologous dental ligament micro-grafts: Case report with 6 months follow-up. Ann. Oral Maxillofac. Surg. 2013, 1, 20. [CrossRef]

13. Marcarelli, M.; Trovato, L.; Novarese, E.; Riccio, M.; Graziano, A. Rigenera protocol in the treatment of surgical wound dehiscence. Int. Wound J. 2017, 14, 277-281. [CrossRef] [PubMed]

14. Carinci, F.; Motroni, A.; Graziano, A.; Zollino, I.; Brunelli, G.; D'Aquino, R. Sinus lift tissue engineering using autologous pulp micro-grafts: A case report of bone density evaluation. J. Indian Soc. Periodontol. 2013, 17, 644-647. [CrossRef] [PubMed]

15. Purpura, V.; Bondioli, E.; Graziano, A.; Trovato, L.; Melandri, D.; Ghetti, M.; Marchesini, A.; De Angelis, M.G.C.; Benedetti, L.; Ceccarelli, G.; et al. Tissue characterization after a new disaggregation method for skin micro-grafts generation. J. Vis. Exp. 2016. [CrossRef]

16. Izumi, K.; Tobita, T.; Feinberg, S.E. Isolation of human oral keratinocyte progenitor/stem cells. J. Dent. Res. 2007, 86, 341-346. [CrossRef]

17. Graziano, A.; D'Aquino, R. From the research to the clinical practice: The micro-grafts challenge. In Proceedings of the 4th World Congress on Cell Science \& Stem Cell Research, Valencia, Spain, 24-26 June 2014.

18. D'Aquino, R.; Trovato, L.; Graziano, A.; Ceccarelli, G.; de Angelis, G.C.; Nisio, A.; Galli, M.; Pasi, M.; Finotti, M.; Rizzo, S.; et al. Periosteum-derived micro-grafts for tissue regeneration of human maxillary bone. J. Transl. Sci. 2016, 2, 125-129. [CrossRef]

19. De Francesco, F.; Graziano, A.; Trovato, L.; Ceccarelli, G.; Romano, M.; de Angelis, G.C.; Marcarelli, M.; Cillo, U.; Riccio, M.; Ferrao, G.A. A regenerative approach with dermal micrografts in the treatment of chronic ulcers. Stem Cell Rev. 2017, 13, 139-148. [CrossRef]

20. Ibrahim, S.F.; Engh, G.V.D. High-speed cell sorting: Fundamentals and recent advances. Curr. Opin. Biotechnol. 2003, 14, 5-12. [CrossRef]

21. Zhu, B.; Murthy, S.K. Stem cell separation technologies. Curr. Opin. Chem. Eng. 2013, 2, 3-7. [CrossRef]

22. Rock, K.L.; Kono, H. The inflammatory response to cell death. Annu. Rev. Pathol. 2008, 3, 99-126. [CrossRef] [PubMed]

23. Majno, G.; La Gattuta, M.; Thompson, T.E. Cellular death and necrosis: Chemical, physical and morphologic changes in rat liver. Virchows Arch. Pathol. Anat. Physiol. Klin. Med. 1960, 333, 421-465. [CrossRef] [PubMed]

24. Suárez-López Del Amo, F.; Garaicoa-Pazmiño, C.; Fretwurst, T.; Castilho, R.M.; Squarize, C.H. Dental implants-associated release of titanium particles: A systematic review. Clin. Oral Implants Res. 2018, 29, 1085-1100. [CrossRef] [PubMed]

25. Bio Rad. TC10 ${ }^{\mathrm{TM}}$ Automated Cell Counter with Printer \#1450009. Available online: http:/ /www.bio-rad.com/en-au/sku/145000 9-tc10-automated-cell-counter-with-printer?ID=1450009 (accessed on 15 January 2018).

26. Winter, G.D. Tissue reaction to metallic wear and corrosion products in human patients. J. Biomed. Mater. Res. 1974, 8, 11-26. [CrossRef] [PubMed]

27. Lee, S.-H.; Brennan, F.R.; Jacobs, J.J.; Urban, R.M.; Ragasa, D.R.; Glant, T.T. Human monocyte/macrophage response to cobaltchromium corrosion products and titanium particles in patients with total joint replacements. J. Orthop. Res. 1997, 15, 40-49. [CrossRef]

28. Haynes, D.R.; Rogers, S.D.; Hay, S.; Pearcy, M.J.; Howie, D.W. The differences in toxicity and release of bone-resorbing mediators induced by titanium and cobalt-chromium-alloy wear particles. J. Bone Jt. Surg. Am. Vol. 1993, 75, 825-834. [CrossRef]

29. Dayan, A.D.; Paine, A.J. Mechanisms of chromium toxicity, carcinogenicity and allergenicity: Review of the literature from 1985 to 2000. Hum. Exp. Toxicol. 2001, 20, 439-451. [CrossRef]

30. Gaggelli, E.; Berti, F.; D'Amelio, N.; Gaggelli, N.; Valensin, G.; Bovalini, L.; Paffetti, A.; Trabalzini, L. Metabolic pathways of carcinogenic chromium. Environ. Health Perspect. 2002, 110 (Suppl. 5), 733-738. [CrossRef]

31. Rycroft, R.J.G.; Menn, T.; Frosch, P.J. Textbook of Contact Dermatitis, 3rd ed.; Springer: Berlin, Germany; New York, NY, USA, 2001.

32. Daley, B.; Doherty, A.T.; Fairman, B.; Case, C.P. Wear debris from hip or knee replacements causes chromosomal damage in human cells in tissue culture. J. Bone Jt. Surgery. Br. 2004, 86, 598-606. [CrossRef]

33. Messer, R.L.; Bishop, S.; Lucas, L.C. Effects of metallic ion toxicity on human gingival fibroblasts morphology. Biomaterials 1999, 20, 1647-1657. [CrossRef]

34. Bhowmick, N.A.; Neilson, E.G.; Moses, H.L. Stromal fibroblasts in cancer initiation and progression. Nature 2004, $432,332-337$. [CrossRef] [PubMed]

35. Pietras, K.; Ostman, A. Hallmarks of cancer: Interactions with the tumor stroma. Exp. Cell Res. 2010, 316, 1324-1331. [CrossRef] [PubMed]

36. Hallab, N.J.; Anderson, S.; Caicedo, M.; Brasher, A.; Mikecz, K.; Jacobs, J.J. Effects of soluble metals on human peri-implant cells J. Biomed. Mater. Res. Part A 2005, 74, 124-140. [CrossRef] [PubMed]

37. Hosman, A.H.; van der Mei, H.C.; Bulstra, S.K.; Busscher, H.J.; Neut, D. Effects of metal-on-metal wear on the host immune system and infection in hip arthroplasty. Acta Orthop. 2010, 81, 526-534. [CrossRef] [PubMed]

38. Brodner, W.; Bitzan, P.; Meisinger, V.; Kaider, A.; Gottsauner-Wolf, F.; Kotz, R. Elevated serum cobalt with metal-on-metal articulating surfaces. J Bone Jt. Surg. Br. 1997, 79, 316-321. [CrossRef] 
39. Keegan, G.M.; Learmonth, I.D.; Case, C.P. Orthopaedic metals and their potential toxicity in the arthroplasty patient: A review of current knowledge and future strategies. J. Bone Jt. Surg. Br. 2007, 89, 567-573. [CrossRef] [PubMed]

40. Cobb, A.G.; Schmalzreid, T.P. The clinical significance of metal ion release from cobalt-chromium metal-on-metal hip joint arthroplasty. Proc. Inst. Mech. Eng. H 2006, 220, 385-398. [CrossRef]

41. Ferreira, M.E.; de Lourdes Pereira, M.; Garcia e Costa, F.; Sousa, J.P.; de Carvalho, G.S. Comparative study of metallic biomaterials toxicity: A histochemical and immunohistochemical demonstration in mouse spleen. J. Trace Elem. Med. Biol. 2003, 17, 45-49. [CrossRef]

42. Hasegawa, M.; Iino, T.; Sudo, A. Immune response in adverse reactions to metal debris following metal-on-metal total hip arthroplasty. BMC Musculoskelet. Disord. 2016, 17, 1-5. [CrossRef]

43. Hallab, N.J.; Jacobs, J.J. Biologic effects of implant debris. Bull. NYU Hosp. Jt. Dis. 2009, 67, 182-188.

44. Jomova, K.; Valko, M. Advances in metal-induced oxidative stress and human disease. Toxicology 2011, 283, 65-87. [CrossRef] [PubMed]

45. Ghio, A.J.; Pavlisko, E.N.; Roggli, V.L. Iron and iron-related proteins in asbestosis. J. Environ. Pathol. Toxicol. Oncol. 2015, 34, 277-285. [CrossRef] [PubMed]

46. Jaishankar, M.; Tseten, T.; Anbalagan, N.; Mathew, B.B.; Beeregowda, K.N. Toxicity, mechanism and health effects of some heavy metals. Interdiscip. Toxicol. 2014, 7, 60-72. [CrossRef] [PubMed]

47. Hershko, C.; Link, G.; Cabantchik, I. Pathophysiology of iron overload. Ann. N. Y. Acad. Sci. 1998, 850, 191-201. [CrossRef] [PubMed]

48. Ryan, T.P.; Aust, S.D. The role of iron in oxygen-mediated toxicities. Crit. Rev. Toxicol. 1992, 22, 119-141. [CrossRef]

49. Bhasin, G.; Kauser, H.; Athar, M. Iron augments stage-I and stage-II tumor promotion in murine skin. Cancer Lett. 2002, 183, 113-122. [CrossRef] 